\title{
Pelatihan Pengembangan Biskuit yang Diperkaya Tepung Pisang Tongka Langit dan Ikan Cakalang di Desa Waiheru Kota Ambon
}

\author{
Muhamad Asrar*1, Ety Yuni Ristanti ${ }^{2}$ \\ 1,2Jurusan Gizi Politeknik Kesehatan Kemenkes Maluku \\ *e-mail : muh.asrar4789@gmail.com¹, etyristanti@poltekkes-maluku.ac.id²
}

\begin{abstract}
The purpose of this community service activity is to increase the knowledge and skills of mothers in making Tongka Langit banana and skipjack flours and processing them into biscuits. The method used in this community service activity consists of the preparation of participants, locations, tools and materials, implementation of activities with the delivery of materials and practices. The results of the activity were 30 mothers attended, there was an increase in participants' knowledge about the nutritional value and benefits of tongka langit bananas, skipjack fish, how to make flour and biscuits enriched with tongka langit bananas and skipjack flours. All participants were able/skilled in making biscuits enriched with banana flour tongka Langit and skipjack tuna.
\end{abstract}

Keywords : Training, Biscuits, Tongka Langit banana, Skipjack Fish

\begin{abstract}
Abstrak
Tujuan kegiatan pengabdian kepada masyarakat ini untuk meningkatkan pengetahuan dan ketrampilan ibu-ibu dalam membuat tepung pisang tongka langit dan tepung ikan cakalang serta mengolahnya menjadi biskuit. Metode yang dilakukan pada kegiatan pengabdian kepada masyarakat ini terdiri dari persiapan peserta, lokasi, alat dan bahan, pelaksanaan kegiatan dengan penyampaian materii dan praktik. Hasil pelaksanaan kegiatan yaitu peserta hadir sebanyak 30 orang ibu, terdapat peningkatan pengetahuan peserta tentang nilai gizi dan manfaat pisang tongka langit, ikan cakalang, cara pembuatan tepung dan biskuit yang diperkaya pisang tongka langit dan ikan cakalang, nilai rata-rata meningkat dari 38 menjadi 79. Dari 30 peserta 100\% mengalami peningkatan pengetahuan. Semua peserta mampu/terampil dalam membuat biskuit yang diperkaya tepung pisang tongka langit dan ikan cakalang.
\end{abstract}

Kata Kunci: Pelatihan, Biskuit, Pisang Tongka Langit, Ikan Cakalang

\section{PENDAHULUAN}

Kota Ambon merupakan ibukota provinsi Maluku dengan luas daratan 359,45 km² dan luas lautan 17,55 $\mathrm{Km}^{2}$ dengan panjang garis pantai $98 \mathrm{Km}$. Wilayah administratis kota Ambon sesuai Peraturan Pemerintah Nomor 13 Tahun 1979 dengan luas $377 \mathrm{Km}^{2}$ atau 2/5 dari luas Pulau Ambon (Dinas Komunikasi Informatika dan Persandian Kota Ambon, 2018). Jumlah penduduk kota Ambon pada tahun 2019 sebesar 384.132 jiwa yang terdiri dari 192.778 laki-laki dan 191.354 perempuan (BPS Kota Ambon, 2020).

Lahan pertanian di Kota Ambon tidak mengalami perubahan, yaitu terdapat 21.113 Hektar. Hasil pertanian di Kota Ambon diantaranya adalah tanaman sayuran, tanaman palawija, dan tanaman buah-buahan. Produk unggulan hasil pertanian Kota Ambon menurut data Dinas Pertanian Kota Ambon yaitu pisang tongkat langit. Pada tahun 2017 produksi pisang tongkat langit di Kota Ambon mencapai 150 ton.

Pisang tongka langit (Musa troglodytarum L.) merupakan salah satu jenis tanaman pisang di Indonesia yang hanya ditemukan di wilayah Indonesia Timur yaitu di kepulauan Maluku dan Papua (Ploetz et al., 2007). Pisang tongka langit mudah mengalami kerusakan jika tertunda pengolahannya atau tidak habis dikonsumsi, oleh karena itu perlu dilakukan upaya diversifikasi terhadap pisang tongka langit. Pisang tongka langit dapat diolah menjadi bahan setengah jadi berupa tepung yang dapat diaplikasikan menjadi biskuit (Picauly \& Tetelepta, 2016). Selain memiliki wilayah daratan, Kota Ambon juga memiliki wilayah perikanan yang kaya 
akan hasil perikanan. Produksi perikanan di kota Ambon tahun 2019 sebesar 25.176,93 ton dan ikan cakalang merupakan jenis ikan yang banyak produksinya. Olahan ikan cakalang sebagai cakalang asap sebesar 4.739,36 ton (BPS Kota Ambon, 2020). Sifat produk perikanan yang mudah rusak merupakan masalah yang memerlukan penanganan dan pengolahan yang baik. Untuk mencegah proses pembusukan agar produk yang melimpah itu dapat dimanfaatkan, maka perlu dikembangkan berbagai cara penanganan dan pengawetan yang tepat salah satunya diolah menjadi tepung (Fatmawati \& Mardiana, 2014)

Desa Waiheru merupakan salah satu desa di wilayah kecamatan Baguala kota Ambon. Desa Waiheru terletak pada wilayah pesisir dan dataran tinggi seluas $2250 \mathrm{H}$ dan panjangnya sekitar 1,5 Km dengan jarak tempuh ke ibu kota Ambon adalah $17 \mathrm{Km}$. Adapun letak Desa Waiheru sebelah utara berbatasan dengan petuanan Hitu, sebelah selatan berbatasan dengan Perairan Teluk Ambon, sebelah barat berbatasan dengan desa Hunut/Durian Patah, sebelah timur berbatasan dengan Desa Nania. Desa waiheru terdiri dari 5 RW dan 26 RT, di huni oleh 12.524 jiwa, dan kurang lebih ada 86 jiwa (suami istri) atau 43 kepala keluarga memiliki profesi dibidang pertanian. Desa Waiheru adalah desa subur dengan kekayaan alam yang cukup melimpah, namun kurangnya skill serta pengetahuan masyarakat menjadikan sumber daya alam tersebut belum termanfaatkan secara maksimal, diantaranya pisang tongka langit dan ikan cakalang. Selama ini masyarakat mengolah pisang tongka langit menjadi pisang rebus dan pisang goreng, sedangkan ikan cakalang diolah menjadi ikan cakalang asar dan abon. Berdasarkan wawancara dengan 10 ibu-ibu di Desa Waiheru, menunjukkan semua ibu belum mengetahui cara membuat tepung pisang tongka langit dan tepung ikan cakalang, $40 \%$ ibu mengetahui cara membuat biskuit, namun belum mengetahui cara membuat biskuit yang diperkaya dengan tepung pisang tongka langit dan ikan cakalang.

Pengolahan pangan merupakan salah satu cara untuk mempertahankan daya awet dan juga meningkatkan nilai ekonomis dari pangan tersebut. Untuk meningkatkan pemanfaatan dan nilai tambahnya, pisang tongka langit dan ikan cakalang dapat diolah menjadi tepung ikan, yang selanjutnya dapat dimanfaatkan menjadi berbagai macam produk makanan salah satunya adalah biskuit (Litaay \& Santoso, 2013). Biskuit merupakan salah satu makanan kering yang digemari oleh masyarakat luas dari berbagai kalangan dan usia. Makanan yang dikenal dengan baik oleh masyarakat sering kali menjadi media untuk bahan-bahan fortifikan karena dengan begitu nutrisi yang ditambahkan dalam produk tersebut akan lebih banyak dikonsumsi oleh lebih banyak orang (Pratama, et al., 2014).

Mailoa, (2013) telah melakukan penelitian penambahan tepung ikan pada campuran tepung pisang tongka langit dan tepung terigu pada pembuatan biskuit. Hasilnya menunjukkan bahwa penambahan tepung ikan $10 \%$ pada biskuit dengan perbandingan $40 \%$ tepung pisang dan $60 \%$ tepung terigu dapat diterima dan disukai oleh konsumen dan memiliki kandungan karbohidrat dan protein yang cukup tinggi (karbohidrat : 77.38\%, protein : 9.07\%) sedangkan kandungan vitamin C (0.23\%) dan $\beta$-karoten (0.19\%). Penelitian Asrar and Ristanti, (2020) menunjukkan rata-rata pertambahan berat badan pada kelompok kontrol (diberikan biskuit susu) adalah 0,33 kg dan kelompok perlakuan (diberikan biskuit yang diperkaya pisang tongka langit ddan ikan cakalang) sebesar $0,83 \mathrm{~kg}$, sedangkan pertambahan tinggi badan kelompok kontrol adalah $0,13 \mathrm{~cm}$ dan kelompok perlakuan adalah $0,24 \mathrm{~cm}$. Terdapat perbedaan yang signifikan $(\mathrm{p}<0,05)$ pertambahan berat badan antara kelompok kontrol dan kelompok perlakuan.

Tujuan kegiatan pengabdian kepada masyarakat ini untuk meningkatkan pengetahuan dan ketrampilan ibu-ibu dalam membuat tepung pisang tongka langit dan tepung ikan cakalang serta mengolahnya menjadi biskuit. 


\section{METODE}

\section{Lokasi dan Partisipan Kegiatan}

Kegiatan pengabdian kepada masyarakat dalam bentuk pelatihan pengolahan biskuit yang diperkaya tepung pisang tongka langit dan ikan cakalang dilakukan di Desa Waiheru pada tanggal 21 - 22 Oktober 2020. Partisipan kegiatan pelatihan ini adalah 30 ibu-ibu di Desa Waiheru.

\section{Bahan dan alat}

Bahan dan alat yang digunakan dalam pelatihan ini adalah modul pengembangan biskuit yang diperkaya pisang tongka langit dan ikan cakalang sebagai makanan tambahan balita, video cara pembuatan tepung pisang tongka langit, tepung ikan cakalang dan pengolahan biskuit diperkaya pisang tongka langit dan ikan cakalang. Instrumen pre dan pos tes untuk menilai pengetahuan ibu tentang pengolahan biskuit yang diperkaya pisang tongka langit dan ikan cakalang.

\section{Metode pelaksanaan kegiatan}

Persiapan pelatihan

Tim pelaksana pengabdian berkoordinasi dengan Kepala Desa Desa Waiheru untuk mennsosialisasikan kegiatan pengabdian kepada masyarakat dan mengurus perijinan, mempersiapkan peserta pelatihan, waktu dan tempat pelatihan, serta mempersiapkan alat dan bahan pelatihan

\section{Pelaksanaan Pelatihan}

Pelaksanaan pelatihan pada hari pertama adalah penyampaian materi tentang kandungan gizi dan manfaat dari pisang tongka langit, ikan cakalang, biskuit yang diperkaya tepung pisang tongka langit dan ikan cakalang, cara membuat tepung pisang tongka langit, tepung ikan cakalang dan biskuit yang diperkaya tepung pisang tongka langit dan ikan cakalang. Metode yang digunakan yaitu ceramah dan diskusi. Peserta diberikan modul panduan pembuatan tepung pisang tongka langit, ikan cakalang dan cara pembuatan biskuit yang diperkaya tepung pisang tongka langit dan ikan cakalang. Kegiatan hari kedua adalah demo pembuatan tepung pisang tongka langit dan tepung ikan cakalang kemudian dilanjutkan praktik membuat biskuit yang diperkaya pisang tongka langit dan ikan cakalang serta membagikan biskuit kepada anak-anak di Desa Waiheru.

Evaluasi Pelatihan

Evaluasi terhadap pengetahuan ibu dilakukan dengan pre test sebelum penyampaian materi dan post test setelah penyampaian materi sedangkan evaluasi terhadap ketrampilan ibu dalam membuat biskuit yang diperkaya pisang tongka langit dan ikan cakalang dilakukan dengan pengamatan dengan menggunakan lembar observasi.

\section{HASIL DAN PEMBAHASAN}

Kegiatan pelatihan dilakukan selama dua hari yang diikuti oleh 30 ibu-ibu di Desa Waiheru. Sebelum penyampaian materi, peserta diberikan pre tes untuk mengetahui pengetahuan ibu. Hasil pre test dapat dilihat pada gambar 1. 


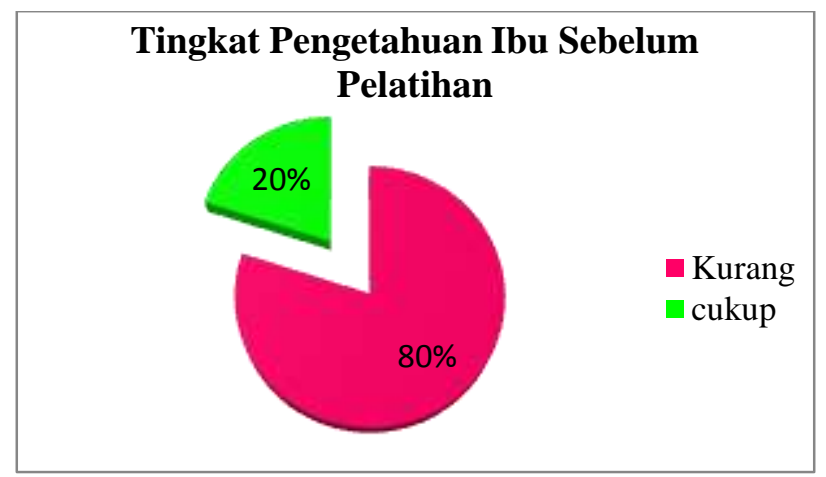

Gambar 1. Hasil Pre Test

Evaluasi awal yang dilakukan sebelum diberikan pelatihan menunjukkan sebagian besar pengetahuan ibu tentang pembuatan tepung pisang tongka langit, tepung ikan dan biskuit yang diperkaya tepung pisang tongka langit dan ikan cakalang, serta manfaat dan kandungan gizinya masih kurang (80\%). Nilai rata-rata adalah 38, nilai terendah 25 dan nilai tertinggi 67.

Kegiatan pelatihan hari pertama adalah penyampaian materi secara teoritis kepada mitra. Penyampaian materi bertujuan untuk memberikan pemaham teoritis kepada mitra. Materi yang disampaikan yaitu kandungan gizi dan manfaat dari pisang tongka langit, ikan cakalang, biskuit yang diperkaya tepung pisang tongka langit dan ikan cakalang, cara membuat tepung pisang tongka langit, tepung ikan cakalang dan biskuit yang diperkaya tepung pisang tongka langit dan ikan cakalang. Kandungan gizi pada tepung pisang tongka langit, yaitu energi sebesar 331,03 kalori, protein 4,66\%, karbohidrat 83,72\%, dan serat pangan total 16,59\%. Tepung pisang ini mengandung 7,92 mg/100 mg total karotenoid dengan kandungan beta karoten sebesar $18,56 \%$. Selain itu, tepung pisang ini juga mengandung komponen antioksidan berupa flavonoid sebesar $0,35 \mathrm{mg} / \mathrm{kg}$ dan aktivitas antioksidan yang cukup tinggi (Pratiwi \& Krisbianto, 2019)

Biskuit yang diperkaya tepung pisang tongka langit dan ikan cakalang mempunyai kandungan karbohidrat dan protein diatas standar SNI biskuit asal tepung terigu dan mengandung beta karoten (Mailoa, 2013). Peserta mendapatkan modul panduan pembuatan tepung pisang tongka langit, ikan cakalang dan cara pembuatan biskuit yang diperkaya tepung pisang tongka langit dan ikan cakalang. Setelah penyampaian materi dilanjutkan dengan diskusi. Peserta aktif mengikuti pelatihan yang ditunjukkan dengan banyak pertanyaan yang diajukan oleh peserta. Hal ini serupa dengan kegiatan pengabdian masyarakat berupa pelatihan yang dilakukan terhadap 30 ibu-ibu di desa Aeng Batu-Batu kecamatan Galesong Utara yang dilakukan dengan penyampaian materi dan dilanjutkan dengan praktik pengolahan ikan katombo menjadi keripik (Amiruddin, et al., 2020).

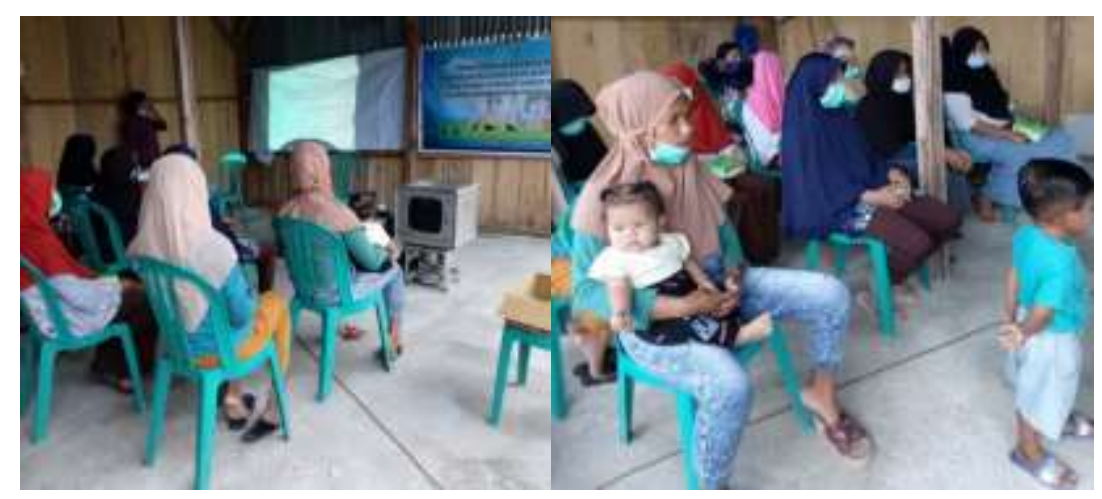

Gambar 2. Penyampaian materi 
Pada akhir dilakukan evaluasi, peserta kembali diberikan posttest dari kegiatan pelatihan. Post test diberikan untuk mengevaluasi tujuan pencapaian dari pelatihan. Hasil post test dapat dilihat pada gambar 3.

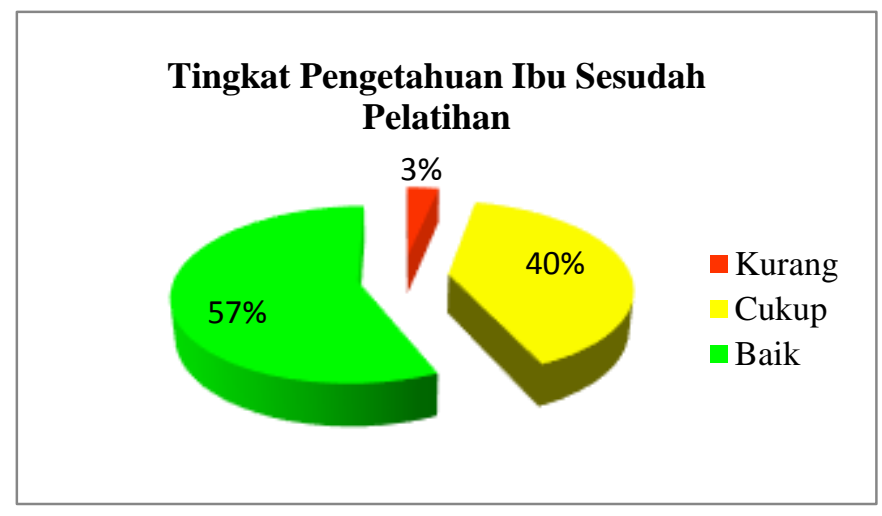

Gambar 3. Hasil Post Test

Evaluasi pada akhir pelatihan menunjukkan bahwa sebagian besar (57\%) tingkat pengetahuan ibu baik dan 3\% pengetahuannya masih kurang. Hal ini menunjukkan bahwa dengan diberikan pelatihan meningkatkan pengetahuan ibu. Nilai rata-rata pengetahuan ibu sesudah diberikan pelatihan adalah 79. Nilai teredah 42 dan tertinggi 100. Dari 30 peserta $100 \%$ mengalami peningkatan pengetahuan setelah diberikan pelatihan. Rata-rata peningkatan pengetahuan ibu adalah 40,56 $\pm 9,2 \mathrm{SD}$.

Kegiatan hari kedua adalah demo pembuatan tepung pisang tongka langit, tepung ikan cakalang kemudian dilanjutkan dengan praktik pembuatan biskuit yang diperkaya tepung pisang tongka langit dan ikan cakalang. Praktik dilakukan oleh masing masing kelompok. Tiap kelompok terdiri dari 3 orang. Pada kegiatan praktik ini didampingi oleh tim pengabdi. Selanjutnya biskuit hasil praktik dibagikan kepada anak-anak disekitar tempat pelatihan.

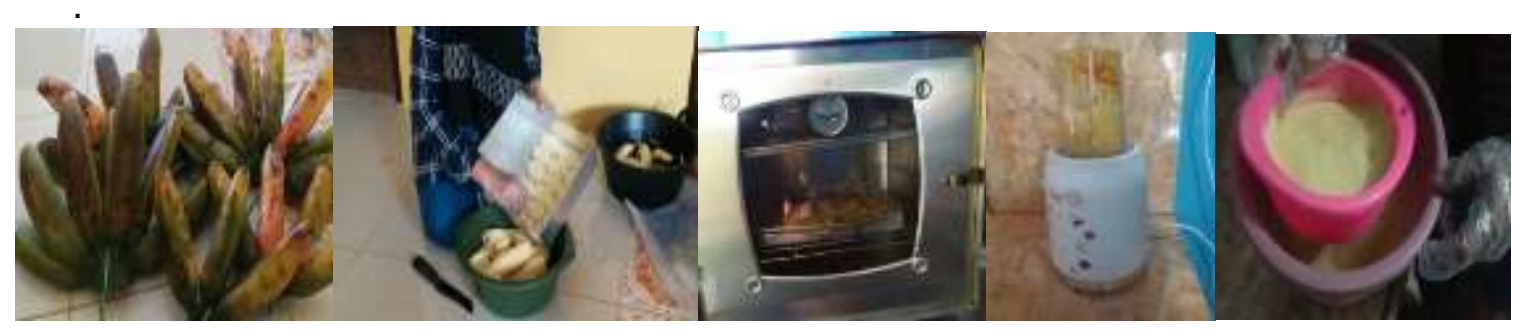

Gambar 4. Demo pembuatan tepung pisang tongka langit

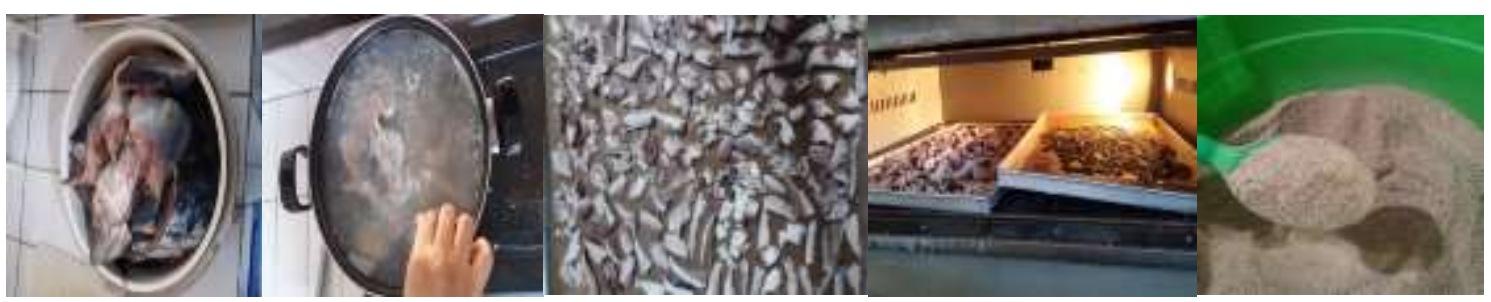

Gambar 5. Demo pembuatan tepung ikan cakalang 


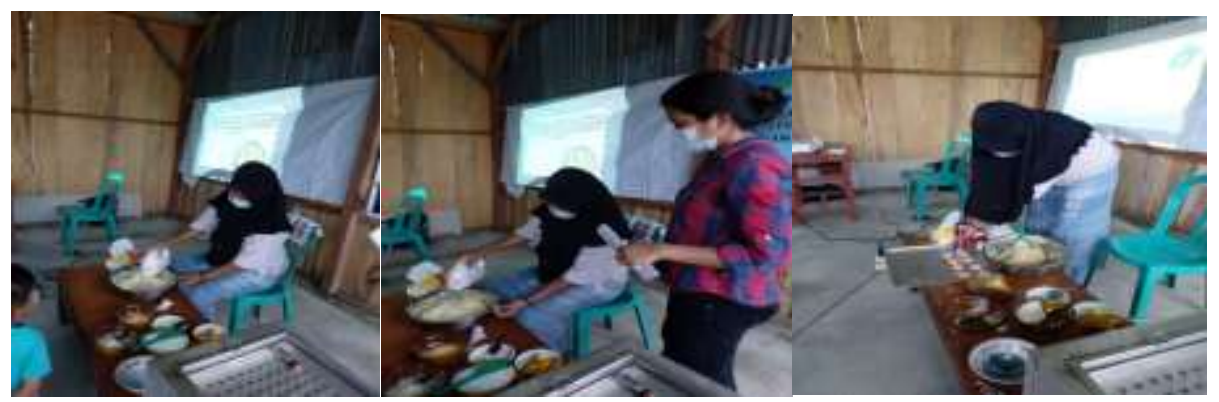

Gambar 6. Praktik pembuatan biskuit yang diperkaya tepung pisang tongka langit dan ikan cakalang

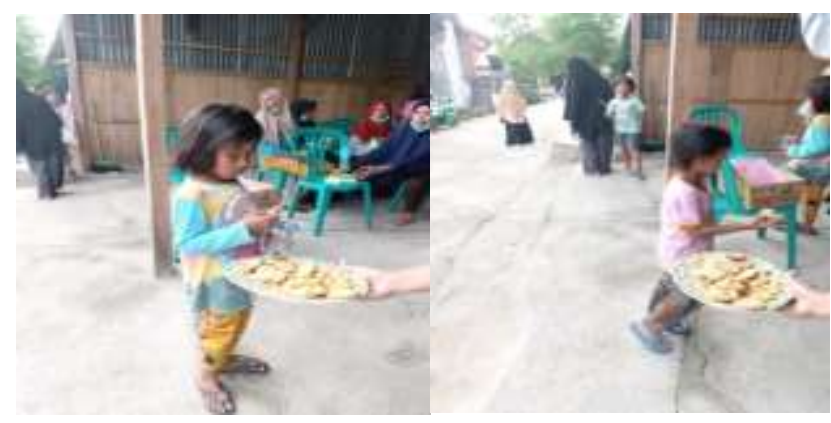

Gambar 7. Pembagian biskuit kepada anak-anak

Selama kegiatan praktik dilakukan pengamatan dengan menggunakan lembar observasi untuk mengetahui ketrampilan peserta dalam membuat biskuit yang diperkaya tepung pisang tongka langit dan ikan cakalang. Hasil pengamatan menunjukkan $100 \%$ atau 30 peserta mampu mempraktikan cara membuat biskuit yang diperkaya tepung pisang tongka langit dan ikan cakalang. Hal ini menunjukkan bahwa kegiatan pelatihan dalam bentuk praktik dapat dikatakan berhasil karena semua peserta mampu mempraktikkan materi yang diberikan. Hal ini sejalan dengan kegiatan pengabdian masyarakat yang dilakukan oleh Mitra et al., (2019) pemberian edukasi kepada ibu balita dalam mengolah menu MP-ASI maka akan meningkatkan pengetahuan dan keterampilan ibu dalam mengolah MP-ASI sehingga dapat meningkatkan status gizi balita.

\section{Luaran yang dihasilkan}

Kegiatan pelatihan yang diadakan di Desa Waiheru menghasilkan beberapa luaran, yaitu 1. Diversifikasi produk dari pisang tongka langit dan ikan cakalang seperti biskuit (Gambar 8);

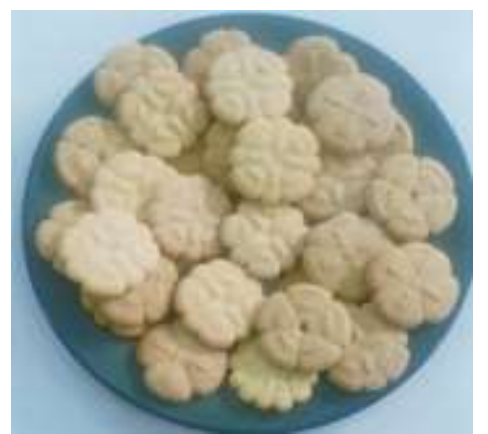

Gambar 8. Biskuit yang diperkaya tepung pisang tongka langit dan ikan cakalang

2. Peningkatan kualitas produk seperti meningkatnya nilai gizi dan nilai sensori dari produk yang dihasilkan. Hal ini mengacu pada beberapa hasil penelitian yang telah dilakukan Mailoa, 2013; Asrar dan Ristanti, 2018 dengan mengsubtitusi penggunaan 
tepung terigu dengan tepung pisang tongka langit dan ikan cakalang dalam membuat biskuit dapat meningkatkan nilai gizi dan nilai sensori biskuit.

3. Berdasarkan hasil evaluasi kegiatan pelatihan dengan metode menggunakan kuesioner bahwa pengetahuan dan keterampilan ibu-ibu bertambah setelah mengikuti pelatihan ini. Pengetahuan peserta tentang nilai gizi dan manfaat pisang tongka langit, ikan cakalang dan biskuit yang diperkaya pisang tongka langit dan ikan cakalang meningkat, nilai rata-rata meningkat dari 38 menjadi 79 . Dari 30 peserta $100 \%$ mengalami peningkatan pengetahuan. $100 \%$ peserta mampu/terampil dalam membuat biskuit yang diperkaya pisang tongka langit dan ikan cakalang.

4. Modul dan Video Pembuatan Tepung Pisang Tongka langit, tepung ikan cakalang dan biskuit yang diperkaya tepung pisang tongka langit dan ikan cakalang

\section{KESIMPULAN}

1. Kegiatan pelatihan dapat terlaksana dengan baik, sebanyak 30 ibu-ibu di Desa Waiheru dilatih cara membuat tepung pisang tongka langit, ikan cakalang dan biskuit yang diperkaya tepung pisang tongka langit dan ikan cakalang

2. Terdapat peningkatan pengetahuan peserta tentang nilai gizi dan manfaat pisang tongka langit, ikan cakalang, cara pembuatan tepung dan biskuit yang diperkaya pisang tongka langit dan ikan cakalang, nilai rata-rata meningkat dari 38 menjadi 79. Dari 30 peserta $100 \%$ mengalami peningkatan pengetahuan.

3. Semua peserta mampu/terampil dalam membuat biskuit yang diperkaya tepung pisang tongka langit dan ikan cakalang.

\section{DAFTAR PUSTAKA}

Amiruddin, Nuraeni, Trimulato, Muhlis, \& Mustamin, A. (2020). Pelatihan Usaha Desa Melalui Pengolahan Ikan Katombo Di Desa Aeng Batu-Batu Kecamatan Galesong Utara Kabupaten Takalar Sulawesi Selatan. Abdimas Unwahas, 5(1), 21-27.

Asrar, M., \& Ristanti, E. (2020). Efficacy of Biscuits Enriched With Banana Sky ( Musa Troglodyarium ) and Flour Tuna Skipjack As a Supplementary Food For Underweight Children Under-Fiveyears in Ambon, 8(1), 29-38.

Dinas Komunikasi Informatika dan Persandian Kota Ambon. (2018). Statistik Sektoral Kota Ambon 2018. Ambon: (C) Dinas Komunikasi, Informatika, dan Persandian Kota Ambon.

Fatmawati, \& Mardiana. (2014). Tepung Ikan Gabus Sebagai Sumber Protein (Food Supplement). Jurnal Bionature, 15(1), 54-60.

Litaay, C., \& Santoso, J. (2013). Pengaruh Perbedaan Metode Perendaman dan Lama Perendaman terhadap Karakteristik Fisiko-Kimia Tepung Ikan Cakalang (Katsuwonus pelamis). Ilmu Dan Teknologi Kelautan Tropis, 5(1), 85-92.

Mailoa, M. (2013). Penambahan Tepung Ikan Pada Campuran Tepung Pisang Tongka Langit dan Teung Terigu Untuk Dijadikan Biskuit. Ekosains, 2(1).

Mitra, Septiani, W., Susmaneli, H., \& Nurlisis. (2019). Meningkatkan Status Gizi Balita Melalui Praktek Pegolahan Makanan Pendamping ASI BUatan Sendiri. DINAMISIA: Jurnal Pengabdian Kepada Masyarakat, 3(2), 208-213.

Picauly, P., \& Tetelepta, G. (2016). Uji Organoleptik Crackers Pisang Tongka Langit. AGRITEKNO, Jurnal Teknologi Pertanian, 5(2), 53. https://doi.org/10.30598/jagritekno.2016.5.2.53

Pratama, R., Rostini, I., \& Liviawaty, E. (2014). Karakteristik Biskuit Dengan Penambahan Tepung Tulang Ikan Jangilus (Istiophorus Sp.). Jurnal Akuatika Indonesia, 5(1), 245040.

Pratiwi, I. Y., \& Krisbianto, O. (2019). Kandungan Gizi, Beta Karoten dan Antioksidan pada Tepung Pisang Tongka Langit (Musa troglodytarum L.). AgriTECH, 39(1), 48. https://doi.org/10.22146/agritech.32335 